\title{
Communication Styles in EFL Classroom Interaction
}

\author{
Jusriati $^{1}$, Nasriandi ${ }^{2}$, Puspa Sari ${ }^{3}$ \\ ${ }^{1,2,3}$ Universitas Muhammadiyah Palopo \\ 1jusriati@umpalopo.ac.id, 르asriandi@umpalopo.ac.id, puspasari@umpalopo.ac.id

\begin{tabular}{ccc}
\hline Diterima & Direvisi & Disetujui \\
$10-08-2020$ & $26-08-2020$ & $31-08-20$ \\
\hline
\end{tabular}

\begin{abstract}
This research identified types and the dominant communication styles used by a teacher in EFL classroom interaction based on theory of Mikoluk (2013) and Lanz (2015). Descriptive qualitative research method was applied to find out the phenomena of communication styles used by the teacher in EFL classroom interaction. The subject of this research is single participant, a teacher of SMA Negeri 3 Palopo. The participant was chosen by using purposive sampling technique. The researcher observed and interviewed the teacher to reveal the phenomena under investigation. Observation was conducted in six meetings from different context such as different class, time and learning topic. The researcher conducted observation by using audio recorder and field notes. Audio recorder was used to record teacher's utterance in the teaching and learning process. Meanwhile field notes used by the researcher to obtain more accurate data. Interview was used to know the teacher's dominant communication styles. The result of this research showed that there were three types of communication styles that used by the teacher in EFL classroom interaction namely aggressive style, assertive style, and passive style and the dominant one was aggressive style.
\end{abstract}

Key Words :-Communication Styles, EFL Classroom, Classroom Interaction

\begin{abstract}
Abstrak - Penelitian ini bertujuan untuk mengidentifikasi jenis-jenis gaya komunikasi serta menentukan gaya komunikasi yang paling sering digunakan oleh guru dalam pembelajaran Bahasa Inggris.adapun gaya komunikasi yang dimaksudkan dalam artikel ini yaitu merujuk pada teori Mikoluk (2013) dan Lanz (2015. Dalam penelitian ini digunakan metode deskriptif kualitatif dalam menemukan penomena-penomena yang berkaitan dengan gaya komunikasi guru dalam pembelajaran Bahasa Inggris. Penelitian ini menggunakan partisipan tunggal yaitu salah satu guru Bahasa Inggris di SMA Negeri 3 Palopo. partisipan tersebut dipilih dengan menggunakan teknik purposif. Dalam penelitian ini, peneliti melakukan observasi selama enam kali pertemuan di kelas yang berbeda dan dengan materi ajar yang berbeda. Setelah proses observasi peneliti kemudian melakukan interview terhadap partisipan tersebut. Dalam tahap observasi, peneliti menggunakan rekaman audio, dan catatan lapangan sebagai instrumen penelitian. Rekaman audio digunakan sebagai media untuk mereka seluruh ungkapa-ungkapan guru selama proses pembelajaran sementara catatan lapangan digunakan unuk memperoleh data tambahan yang lebih akurat. Selanjutnya interview digunakan untuk mengklarifikasi gaya komunikasi yang paling sering digunakan oleh partisipan tersebut. Hasil dari penelitian ini menunjukan bahwa ada tiga jenis gaya komunikasi yang digunakan oleh guru tersebut dalam proses pembelajarannya yaitu gaya agresif, gaya asertif, dan gaya pasif, dan yang paling sering digunakan adalah gaya agresif tersebut.
\end{abstract}

Kata Kunci : Gaya Komunikasi, Kelas Pembelajar Bahasa Inggris sebagai Bahasa Asing, Interaksi dalam Kelas.

\section{INTRODUCTION}

Generally communication is related to human interaction, through communication we can share our feeling and thought from one to another. For the next insight about communication, Hybel and Weaver in (Luthra \& Dahiya, 2015) stated that communication can be defined as a way to interact with others and it is used to share information and beliefs, exchange ideas and feelings, make plans and solve problems.

Next related to communication in the classroom, it is a common place thing in education.
Particularly for students in senior high school because, during teaching and learning process in the classroom is running, surely at this time the communication in the classroom occurs. But not all of the communication at the time is categorized as an effective communication.

Nowadays there are several researcher are interest to conduct a research about communication in the classroom particularly for EFL classroom because they think that communication in the classroom is one of complicated phenomenon in education fields and it is as a central to classroom activities. As we know teacher has important roles in 
the success and the failure of teaching and learning process. Teacher should interact as a communicative as possible in order to make the students understand what the teacher talks about. .

Referring to the importance of communication in the classroom, the teacher is involved because a she/he is required to create the best learning environment in the classroom interaction by communicating well in the process of teaching and learning. Teaching in the classroom is not merely the process of teaching but it is also the reflection of teacher's communication that is determined to their teaching goals to the students. The relationship between teacher and students in the classroom can create positive classroom environment when there is a supportive relationship between them. Because it can offer chances to students to be motivated and feel engaged in improving the leaning process.

When teaching and learning process of EFL classroom at Senior High School of 3 Palopo the researcher found that the students still have troubles in understanding their teachers' explanation and it is caused by their teachers' communication style when delivering their material such: teachers' voice, intonation, gesture, and thinking style. Teachers' thinking style in here is one of the problem where the teacher sometimes difficult to accept their students opinion, they didn't give their students time to talk with the result that there is no feedback in the classroom. Then, related to the previous problem, we can learn from our experience and we can see in our reality that there are several students are not satisfied with their teachers' style when communicating in the classroom. This is one of the common problems in the classroom, where the students are not comfort about their teachers' communication style when delivering material in the class. And the second one is the teachers don't care about their students' condition, do their students understand or not in relating to their explanation. Based on the cases above, it seems the teachers' communication at the moment is not effective. While, (Croskey, n.d.) stated that school or university is about information and understanding. It means the effective communication plays an important role in the classroom, and it has close relation with teachers' style in communication. Through this study, the reseracher tries to do a new thing that is the researcher is interested to build up the research under the title: Teacher's communication styles in EFL classroom interaction.

\section{METHOD}

This study used descriptive qualiative method and focused on analysing communication styles of one teacher who has a brand with a favorite teacher from students' perception. Then the data from the participant collected through classroom observation and interview. The classroom observation has been done in six meetings as long as 60 minutes for each meeting. It is used to get the information about the communication styles used by the teacher in the process of teaching and learning in EFL classroom. Then the interview was used after completing the classroom observation, where it is used to get additional information about the teacher's dominant communication styles. The semi-structured interviewed was used in this study, where the guide questions involves as many as 15 main questions. Furthermore, in the process of analyzing the data, this study focused three activities namely data reduction, data display, and conslusion drawing/verification(Miles \& Huberman, 1994).

\section{FINDING AND DISCUSSION}

\section{Types and The Dominant Communication Style Used by the Teacher}

From the result of data observation indicates that the most styles of communication used by the recorded teacher in EFL classroom was Aggressive where from 595 utterances, aggressive styles was occurred 433 times $(72.7 \%)$. The next was followed by assertive style, it was occurred 143 times (24\%). And the last communication style was passive style. Based on the data observation it was occurred 28 times $(4.70 \%)$.

Mikoluk and Lanz have conducted research based on the three basic of communication styles. Their research is relevant with this present study where, based on the previous findings that concerned the types of communication styles, it can be seen that there are three types of communication style used by teacher in classroom interaction. Those types are aggressive style, assertive style, and passive style. Those kinds are presented as follows.

The first is aggressive style. Based on classroom observation, the researcher found that a person who uses an aggressive style always put their needs and wants as the first. Besides that, he/she always felt confidence on his/her communication. This is relevant to the Mikoluk's theory (2013) who state that aggressive person behaves as if their needs are the most important, as though they have more to contribute than other people. Next related to the classroom observation, the researcher found that the teacher used aggressive style on his communication in the classroom either in morning class or in the noon class. In this study, both of in the morning and 
noon class, the teacher used aggressive style frequently. It can be seen when the teacher was entering the classroom phase (extract 1 and extract 2).

A person who used an aggressive style is working by bullying and intimidation (Mikoluk, 2013). This theory is in line with the result of this study. Where in the process of teaching and learning in the classroom, the teacher is frequently bullying and intimidating his students, although he didn't aware about it.

Besides that based (Gumanti et al., 2016) there several characteristics of aggressive style such, strident, sarcastic or condescending voice, fluent, few hesitation, often abrupt, clipped, often fast, emphasizing blaming words, firm voice, tone sarcastic, cold, harsh, use of threats, put downs, evaluative comments, racist remarks, boastfulness, opinion expressed as a fact, threatening questions, intimidating, bullying. But from those characteristics, the writer found the new things through this study about the other characteristics aggressive style namely used utterance repetition, and questioning and answering by him self.

The second style is assertive. This is born of high self esteem, Mikoluk in (Suharni et al., 2018) . $\mathrm{He}$ stated that this communication style most commonly associated with confidence from the people who use it. But related to the result of this present research, the researcher found that the participant sometimes over confidence on his performance in the classroom, that's why he more dominant to the aggressive style, because he has a high self-esteem than assertive style.

Based on the (Centre for Clinical Interventions, 2008) there several verbal characteristics of aggressive style such firm and relaxed voice, fluent, few hesitations, steady even pace, tone is middle range, rich and warm, sincere and clear, not over-loud or quiet, voice appropriately loud for the situation, "I" Statements, co-operative phrases, emphatic statements, distinction between fact and opinion, suggestion without "Should or ought", constructive criticism without blame, seeking others opinion, willingness to explore other solutions and accepting for compliments. But from the data observation the writer just found several of them namely giving suggestion, co-operative phrases, showing caring, sincere and clear, express in honest, accepting for compliment and the last is willingness to receive others opinion.

The third style is passive style, as we know that passive style is a way where the communicator is not expressing honest feelings, thoughts, and beliefs. Therefore, allowing others to violate your rights. It can also mean expressing thoughts and feelings in apologetic, self effacing way so that others easily disregard them. It also sometime showing a subtle lack of respect for the other person's ability to take disappointments, shoulder some responsibility, or handle their own problems. Mikoluk (2013) stated that passive communicators are hesitant to express their true feelings, prefer indirect communication methods and are usually apologetic of their own behavior. And this is in line with the result of this study, where based the six meeting of classroom observation, the researcher found the teacher used aggressive style in a little time. in this case, the teacher used the style when he asked his students to speech in front of the class. But at the moment, one of his students refused for doing it. And as the next activity from the teacher, he directly invited another student without using forceful statement. It can be seen in extract 25 .

Based on (Centre for Clinical Interventions, 2008) there are several verbal characteristics of passive style such long rambling sentences, beat around the bush, Frequent throat clearing, fill in words "may be", voice often dull and monotonous, tone may be sing-song or whining, over soft over warm, quiet often dropping away, frequent justifications, apologies, qualifiers, self-dismissal, and self put downs. But from data observation, the writer just found several of them such beat around the bush and long rambling sentences that can be seen in extract 21, filled with word "Eh" and apologize that can be seen in extract 22, hesitant and filled with pauses that can be seen in extract 23, qualifiers statements that can be seen in extract 24 and the last is apologize in appropriate way that can be seen in extract 25 .

Discussing about teaching it covers effective communication in the classroom. According to $(M c$ Crosky Virginia.Pdf, n.d.), effective teachers are effective communicators. They are those who consciously and strategically make decision about what is communicated and how it is communicated. So based on the theory, as a good teacher we have to make our students understand about our explanation and we should be able to decide an appropriate ways in communicating to them.

In the previous chapter the writer has been described about several types of communication styles such from Norton's theory who classified about ten types of communication styles and from psychology fields who classified about it only into three basics of communication styles and it is was supported from and Lanz in (Suharni et al., 2018). Actually although communication style has been classified many times in variety of ways, but most of them agree that there are three basic type of communication styles namely aggressive, assertive and passive. But in this research the researcher tried analyzing the teacher's communication styles from 
the three basics theory, but she also tried concerning the three basic styles and the ten styles from Norton's classification. And she has concluded that aggressive styles covers the dominant, contentious and open style, then assertive styles covers impression leaving, relaxed, attentive, friendly, and precise style. This conclusion is based on the same characteristics from both of the theories. However, this conclusion is not suitable with the previous theory from Mikoluk (2013) who mentioned the dominant communication as the part of assertive styles. But through this present research, the researcher found the new things that the dominant one in this study is refers to the aggressive style.

In the previous chapter of this paper, the writer has explained about a theory dealing with communication style. The impressions that others form about us are based on what they observe us saying and doing. They have no way of knowing our innermost thoughts and feelings, so they make decisions about us based on what they see and hear. Then, what is the relation of this study. In the chapter three the writer has explained that she used the purposive sampling technique in taking the participant. Where, he used a favorite teacher from the students' perception as her participant in this case. And in relating to the findings of this study, in fact the students were judge their students as a favorite teachers because the teacher in the process of teaching and learning process was categorized as an aggressive communicator. Where, he was dominant in the classroom communication.

\section{Frequency of Communication Styles Used by Teachers}

It was found in the finding that the most dominant types of communication styles used by the teacher in EFL classroom interaction at SMAN 3 Palopo during the observations was aggressive styles. It was occurred 433 times during six meeting. In this case, teacher mostly used the style in the class because based on the extracts, as a teacher there are many things that can be asked and informed to the students in relation with effectiveness of teaching and learning process. Properly it becomes the dominant because the teacher character who has an orator, that's why he tried to be dominant in every communication. The second style was assertive style. It was occurred 143 times from the first meeting until the sixth meeting. The last expression was passive style. This style occurred 28 times during six meeting. Most of this style appeared when the teacher gave an example to his students and tried to relate the real students' experience and his explanation.

According to (Hanif, 2012), since a person's communication styles is a combination of two or more, one identified as dominant communication styles. Referring to the result of this study, it indicates that from the three communication styles used by the teacher in EFL classroom interaction, aggressive styles as the dominant communication used by him.

Others person make a decision about us based on what they see and hear. And it the patterns of behavior that others can be observe. It can be called as communication styles. Related to the research findings about the teacher's communication styles in the classroom, the researcher found that the dominant communication styles used by the teacher was aggressive styles. And it has been concluded from the researcher's observation in the classroom toward what the teacher has been saying and done during the process of teaching and learning in the classroom. Then discussing about the aggressive styles, (Ranger et al., 1992) have conducted a previous research about the relationship between self-esteem and aggressive communication predisposition. Based on their research, they found that there is significant and positive relation between self-esteem (personal power and competence) in trait argumentativeness. It can be stated that, one whose has a high self-esteem can be more aggressive in their communication. And this consistent with the result of this present research where, during teaching in the classroom the teacher's performance was totally active and this is because he has a high-selfesteem, that's why he always used the aggressive style on his communication.

Teachers' non-directive communication styles encourage the students become co-creator of the teaching process. It nurtures his or her curiosity, creatively, his or her own experience and the autonomy in the learning process (Kos $\breve{A}-k o v \breve{A}^{2}$, 2015). Then related to the result of this present study which is focused on the teacher's verbal communication styles, the researcher found the different matter where based on classroom observation that has been conducted by researcher, she did not find the same thing as the students asked many questions, many argue, many express their opinion, and so forth. Because based on the observations that have been conducted, the researcher found that the teacher did not provide the opportunity for their students for doing it.

While according (Parim \& Sahiner, 2014) an effective teacher needs some life skills like stress management, problem solving, self-consciousness, self regulation, class management, adaptation ability to the new situations, creativity, communication skills. Communications skills including listening skills, writing skills, body language, effective speaking are important for teachers to improve their career, to solve the problems in the class, school or in the society and it is the way of personal happiness. Then referring to the result of this present 
study, the researcher found that the teacher didn't develop well about his communication skills, such how should he listened about his students' opinions, how to solve problem in the classroom and so on. It can be seen in extract 5 where, the teacher asked the other students for answering a question while in the previous time he has asked a student for doing it and without giving clarification he directly moved to the next one. From this case, it can be stated that in this situation the teacher didn't act as a good listener.

Basically most of people think that in different context of communication, the communicator will use the different style on their communication. It also has been expressed that communication and culture have a great influence on each other. With changing times, the socioeconomic conditions of individuals are also changing. The effect of these changes is reflected in the communication behavior of people. But related to the result of classroom observation in this research, the researcher found that from the three different class, different time and different learning topic, the teacher was shown one the dominant communication style that is aggressive style. So based on the findings, the researcher reveal that everyone has one or more styles in communication but they absolutely have the dominant one and this dominant style surely will appeared when the people communication although from the different context.

Context is one of the processes of communication. It involves the environment where the communication occurs in which the audience is in, the culture of the organization and elements such as relationship between audiences and communicators (Suharni et al., 2018). Took into Japanese communication styles, (Marková, n.d.) explained that the Japanese way of communication categorized as relation oriented than purpose oriented. And this is because of the context of Japanese, where it is essential for them to care about his partner condition and situation when communicated such caring to gender, age, social status, educational background, occupation and so on. While related to the result of this present study, the researcher found that the teacher's communication in the classroom context categorized as purpose oriented. It can be seen from the teacher's dominant communication styles in EFL classroom was aggressive style. from the findings the researcher highlighted that in the process of teaching and learning in the classroom the aggressive style was the dominant one, it is caused his purposed in the process of teaching namely to make their students understand well about his explanation. But according to researcher, she conclude that, as a good teacher it is not enough for us only to make the students understand about our explanation, but also we should be able to make our students comfort $b$ creating a favorable atmosphere and it can be achieve by managing our appropriate communication styles when teach them.

\section{CONCLUSION}

This research revealed that There were three types of communication styles that used by the teachers in EFL classroom interaction namely aggressive style, assertive style, and passive style. And From the result of data analysis, it was found that the most dominant was aggressive style. according to the previous theory, most of literature stated that the assertive style is the healthiest one that the teacher can use, but it differs from the result of this study where the students in SMAN 3 Palopo like their teacher communication styles that is dominant with aggressive styles because they have categorized their teacher as the favorite one. But it may happen because of the researcher way in choosing the participant. Where she only directly pointed a teacher as participant who has brand favorite teacher by voting the students, without asking them about how their perception of favorite teacher. So, through this research I suggest that this research is can be extended but with different ways in taking the participant such asking the students about their perception on favorite teachers and so on. Besides that, it also can be extended by conducting the research in other different content and setting. It will be more interesting to investigate deeply about communication styles. For instance by adding the non-verbal communication style, and asking for the students' interpretation about their teachers' communication style.

\section{REFERENCES}

Centre for Clinical Interventions. (2008). Assert yourself! How to recognise Assertive Behaviour. Assert Yourself, Two, 110.croskey. (n.d.).

Gumanti, A., Yudiar, ., \& Syahruddin, . (2016). Metode penelitian pendidikan. In Jakarta: mitra wacana merdeka.

Hanif, A. (2012). Communication Style of Employed and Unemployed Men and Women in Pakistan. 3(19), 228-235.

Kos Ă-kovǍ , V. (2015). Communication Styles in Teaching and their Psycho-Didactic Aspects. Studia Edukacyjne, 30, 321-329. https://doi.org/10.14746/se.2014.30.18

Luthra, A., \& Dahiya, K. (2015). Organizational Communication and Management Effectiveness: An analytical Study at Various 
Managerial Levels. InternatIonal Journal of ManageMent \& BusIness StudIes, 5(3), 22309519. http://www.ijmbs.com/Vol5/3/9-anchalluthra.pdf

Marková, V. (n.d.). The Japanese Communication Style - A Review of Research Literature. June 2011.mc crosky virginia.pdf. (n.d.).

Miles, M., \& Huberman, A. (1994). Miles and Huberman Chapter 2. In Qualitative Data Analysis.

Parim, G. A., \& Sahiner, D. S. (2014). The Communication Styles Used by Teachers in Numerical Lessons. Procedia - Social and Behavioral Sciences, 116, 2485-2488. https://doi.org/10.1016/j.sbspro.2014.01.597

Ranger, A. S., Kosberg, R. L., \& Silvestri, V. N. (1992). The Relationship Between SelfEsteem and Aggressive Communication Predispositions. Communication Research Reports.

https://doi.org/10.1080/08824099209359894

Suharni, Atmowardoyo, H., \& Salija, K. (2018). Communication Styles used by Effective EFL Teachers in Classroom Interaction. Elt Worldwide, 5(2), 97-113. https://doi.org/10.26858/eltww.v5i2.7332 